JPDN ISSN 2579-6461 (Online) ISSN 2460-6324 (Print)

Jurnal Pendidikan Dasar Nusantara

Volume 6 | Nomor 1 | Juli 2020 |

DOI:

\title{
PENGARUH MODEL BRAIN BASED LEARNING (BBL) BERBASIS EKSPERIMEN TERHADAP HASIL BELAJAR SISWA KELAS V SEKOLAH DASAR
}

\author{
Riska Tri Erlita ${ }^{1}$, Esti Untari², dan Sri Murdiyah ${ }^{3}$ \\ riskata29@gmail.com ${ }^{123}$ \\ Universitas Negeri Malang \\ No Handphone: +6289690456811
}

\begin{abstract}
Abstrak: Pelaksanaan Pembelajaran tematik tema 7 subtema 3di kelas V SDN Sumberpucung 6 lebih sering menggunakan model pembelajaran konvensional. Selain itu, metode yang digunakan yaitu metode ceramah dan penugasan. Tujuan dilakukannya penelitian untuk mengetahui pengaruh model Brain Based Learning (BBL) berbasis eksperimen terhadap hasil belajar tema 7 subtema 3 peristiwa mengisi kemerdekaan. Pendekatan yang digunakan pendekatan kuantitatif dengan jenis penelitian menggunakan metode eksperimen. Hasil uji soal pretest yaitu data berdistribusi normal dan homogen, pada uji hipotesis memperoleh hasil 0,15>0,05 artinya $\mathrm{H}_{0}$ diterima. Setelah kelas eksperimen dan kelas kontrol diberi perlakuan, dilakukan posttest. Hasilnya data tersebut berdistribusi normal dan homogen, sedangkan pada uji hipotesis adalah $0,179>0,05$ artinya $\mathrm{H}_{0}$ diterima. Hasil penghitungan $N$ Gain Score kelas eksperimen memperoleh rata-rata 0,3519 sedangkan kelas kontrol 0,2668. Hasil yang diperoleh menunjukkan pembelajaran model BBL tidak ada pengaruh terhadap hasil belajar tena 7 subtema 3 peristiwa mengisi kemerdekaan pada siswa kelas V SDN sumberpucung 6 Kabupaten Malang.
\end{abstract}

Kata Kunci: Pengaruh, Brain Based Learning (BBL), Eksperimen

\section{MODEL INFLUENCE BRAIN BASED LEARNING (BBL) BASED ON EXPERIMENTS ON LEARNING OUTCOMES OF CLASS V STUDENTS ELEMENTARY SCHOOL}

\begin{abstract}
Implementation of thematic learning theme 7 subtheme 3 di class V SDN Sumberpucung 6 more often uses conventional learning models. In addition, the method used is the lecture and assignment methods. The purpose of doing research to determine the effect of the model Brain Based Learning ( BBL) experiment based on learning outcomes of theme 7 subtheme 3 events filling independence. The approach used is a quantitative approach to the type of research using the experimental method. Test results pretest that is, data that are normally distributed and homogeneous, the
\end{abstract}


hypothesis test results are 0.15>0.05, which means $\mathrm{H} 0$ received. After the experimental class and the control class were given treatment, carried out posttest. The result is that the data is normally distributed and homogeneous, while the hypothesis test is $0.179>0.05$, which means $\mathrm{H} 0$ received. Calculation results $N$ Gain Score the experimental class gained an average of 0.3519 while the control class 0.2668 . The results obtained indicate that there is no effect of learning on the BBL model on the results of the theme 7 subtheme 3 event filling independence in fifth grade students of SDN Sumberpucung 6 Malang Regency.

Keywords: Influence, Brain Based Learning ( BBL), Experiment

\section{PENDAHULUAN}

Pendidikan harus dilakukan peserta didik secara sadar agar suasana pembelajaran menjadi lebih aktif. Potensi peserta didik yang dapat dikembangkan ialah kecerdasan dan akhlak mulia. Pendidikan menunjukan adanya proses meliputi aspek pengetahuan, sikap, dan keterampilan. Hal tersebut dapat ditemui dalam proses pembelajaran.

Kegiatan saat proses pembelajaran menentukan tujuan pembelajaran. Tujuan dapat tercapai semua apabila guru memiliki kompetensi yang baik, seperti kompetensi pedagogik. Menurut Indriani (2015:88) kompetensi pedagogik guru merupakan kemampuan yang dimiliki seseorang pendidik untuk diterapkan saat pembelajaran yang meliputi ilmu mendidik, keterampilan dasar mengajar, dan pengelolaan kelas supaya pembelajaran berlangsung secara kidmat serta mencapai tujuan pembelajaran.

Kegiatan pembelajaran dalam satuan pendidikan menggunakan kurikulum 2013 (K-13). Pemerintah mengharapkan K-13 ini dapat menyetak generasi Bangsa Indonesia yang mandiri, kreatif, produktif, dan inovatif. Pembelajaran tematik diharapkan dapat menghasilkan generasi Indonesia tersebut. Pembelajaran tematik merupakan suatu pembelajaran dalam bentuk tema yang mengaitkan beberapa mata pelajaran sehingga mewujudkan pengalaman belajar yang lebih bermakna bagi peserta didik (Effendi, 2009:129).

Pengalaman bermakna saat pembelajaran dapat diperoleh peserta didik malelui konsep-konsep yang dipelajari dari kegiatan yang dilakukan secara langsung. Tujuannya untuk memperoleh pengalaman belajar yang bermakna dan dapat menghubungkan konsep-konsep yang sudah dipelajari oleh peserta didik. Guru saat kegiatan pembelajaran harus lebih inovatif dan kreatif dalam menentukan model pembelajaran, 
mengembangkan bahan ajar, memilah sumber belajar peserta didik, serta membuat media untuk diterapkan dalam pembelajaran. Menurut Fathurrohman (dalam Awarlin, 2019:8) model pembelajaran adalah kerangka konseptual sebagai pedoman guru saat kegiatan pembelajaran dari awal sampai akhir pembelajaran. Model pembelajaran yang digunakan ialah model berbasis otak (Brain Based Learning). Jensen 2011 (dalam Laksmi, Sujana, dan Suryaabadi, 2014) berpendapat bahwa BBL adalah kegiatan pembelajaran yang disampaikan dengan cara menyeimbangkan pemikiran otak dan dirancang secara alami untuk belajar.

Menurut Gulpinar (dalam Nahdi, 2015) yang membedakan model pembelajaran BBL dengan model pembelajaran lainnya adalah ciri-ciri pembelajarannya yang rileks, bersifat membangun atau kontruktif, dan dalam pembelajarannya menekankan aspek kerja sama, cara belajar siswa itu lebih bermakna dan menyenangkan. Hal tersebut dapat meningkatkan hasil belajar. Menurut Dimyati \& Mudjiono (2013: 3) hasil belajar adalah nilai akhir yang diperoleh dari kegiatan interaksi antara siswa dan guru. meningkatkan hasil belajar siswa dapat dilakukan dengan membuat siswa menjadi aktif saat pembelajaran melalui pengalaman langsung. Kegiatan tersebut membuat siswa menjadi lebih mudah dalam memahami konsep materi tematik yang dipelajari, misalnya pengalaman langsung yang diperoleh dari kegiatan eksperimen. Sesuai dengan pendapat Prasojo (2012) menyatakan bahwa metode eksperimen merupakan suatu kegiatan seseorang dengan cara percobaan dimana siswa mengalami sendiri atau secara langsung yang dipelajari.

Berdasarkan hasil observasi di kelas V SDN Sumberpucung 06 Kabupaten Malang. Guru menerangkan Pembelajaran Tematik menggunakan model pembelajaran konvensional. Menurut Ibrahim (2017:202) model konvensional merupakan kegiatan pembelajaran yang objek utama ada pada guru, nilai hasil belajar lebih diutamakan daripada proses, dan siswa kesulitan menyatakan pendapatnya dikarenakan siswa berperan sebagai objek bukan subjek. Metode yang digunakan oleh guru ketika pembelajaran ialah penugasan dan ceramah. Selain metode, media pembelajaran yang digunakan pada materi-materi sebelumnya berupa gambar dan video. Apabila sekolah tidak memiliki media, maka guru berinisatif menggambar di papan tulis atau mencarikannya digoogle yang kemudian akan diperlihatkan kepada peserta didik secara bergantian. Permasalahan lainnya yaitu rata-rata hasil belajar Tematik pada materi 
Panas dan Perpindahnnya belum memenuhi dari Kriteria Ketuntasan Minimal (KKM) yang ditetapkan sekolah yaitu 75. Rata-rata nilai yang diperoleh siswa di kelas V pada materi Panas dan Perpindahannya adalah 73. Kesulitannya siswa kurang bisa memahami konsep pada materi tersebut.

Kesimpulan dari kegiatan wawancara dan observasi di atas menunjukkan saat kegiatan pembelajaran model yang digunakan harus bervariasi dengan menyesuaikan materi yang diajarkan pada saat itu. Seperti pada Tema 7 Subtema 3 Peristiwa Mengisi Kemerdekaan, solusi yang dapat dilakukan dalam pembelajaran ialah menggunakan model BBL berbasis eksperimen. Pembelajaran dengan menggunakan model Brain Based Learning berbasis eksperimen dapat menghasilkan pengalaman belajar yang bermakna dan permanen pada otak, apalagi jika siswa terlibat langsung saat melakukan eksperimen. Pengetahuan siswa yang diperoleh dari hasil kegiatan eksperimen menjadi lebih mudah dalam memahami serta dapat bertahan lama dalam ingatan siswa.

Sesuai dengan hal tersebut, merujuk penelitian Esa (2017) menunjukkan hasil uji hipotesis pemahaman konsep fisika dari kelompok siswa kelas eksperimen lebih tinggi daripada pemahaman konsep fisika dari kelompok siswa kelas kontrol, sedangkan pada penelitian Mustiada, dkk. (2014) menunjukkan nilai siswa dari kelompok eksperimen dengan model BBL bermuatan karakter hasil yang diperoleh lebih tinggi dibandingkan model konvensional. Maka perlu dilakukan suatu penelitian dengan judul "Pengaruh Model Brain Based Learning (BBL) Berbasis Eksperimen Terhadap Hasil Belajar Tema 7 Subtema 3 Peristiwa Mengisi Kemerdekaan Siswa Kelas V SDN Sumberpucung 6". Tujuan dari penggunaan model ini diharapkan dapat mengatasi permasalahan yang ada di lapangan.

\section{METODE}

Pendekatan yang digunakan dalam penelitian ini adalah pendekatan kuantitatif. Desain penelitian menggunakan Eksperimen Semu atau Quasi Experimental dengan menggunakan desain non equivalent control group design. Kelas eksperimen dan kelas kontrol tidak dipilih secara random (Sugiyono, 2019:136).

Tabel 1. Rancangan Penelitian

\begin{tabular}{|l|c|l|c|}
\hline Kelas & Pretest & Perlakuan & Posttest \\
\hline Kelas eksperimen (Model BBL) & $O_{1}$ & $\mathrm{X}$ & $O_{2}$ \\
\hline Kelas kontrol (Model konvensional) & $O_{3}$ & - & $O_{4}$ \\
\hline
\end{tabular}

Sumber: Sugiyono, (2019:138) 
Rancangan pada penelitian ini menggunakan dua kelompok yaitu kelas kontrol dan kelas eksperimen. Sebelum diberi perlakuan kelas kontrol dan kelas eksperimen diberi soal pretest. Setelah diberi perlakuan yang berbeda, dilakukan posttest sebagai tahap akhir untuk menilai hasil dari pengaruh model yang telah digunakan. Teknik pengumpulan data dengan melakukan dokumentasi dan wawancara. Instrumen penelitian yang digunakan yaitu observasi, dan tes hasil belajar. Subyek penelitian adalah siswa kelas $\mathrm{V}_{\mathrm{a}}$ yang berjumlah 25 siswa sebagai kelas eksperimen dan kelas $\mathrm{V}_{\mathrm{b}}$ berjumlah 26 siswa sebagai kelas kontrol. Data penelitian diperoleh melalui kegiatan pembelajaran yang menggunakan model Brain Based Learning (BBL) pada kelas eksperimen, model konvensional pada kelas kontrol, dan tes hasil belajar. Hasil observasi aktivitas guru berlaku sebagai data proses. Data hasil belajar berupa meningkatnya pengetahuan siswa. Analisis data menggunakan analisis statistik deskriptif dengan mendeskripsikan atau menjelaskan tanpa membuat kesimpulan (Sugiono, 2019:241). Uji normalitas, uji homogenitas, dan uji hipotesis merupakan uji prasyarata dalam analisis statistik inferensial. Seluruh perhitungan menggunakan aplikasi SPSS 16.0 for Windows.

\section{HASIL}

Data penelitian berupa tes hasil belajar tema 7 subtema 3 peristiwa mengisi kemerdekaan sebagai hasil dari diterapkannya model BBL berbasis eksperimen pada kelas eksperimen dan model konvensional pada kelas kontrol. Data penelitian dari kelas $\mathrm{V}^{\mathrm{a}}$ sebagai kelas eksperimen berjumlah 25 orang, dan kelas $\mathrm{V}^{\mathrm{b}}$ sebagai kelas kontrol berjumlah 26 orang. Hasil analisis deskriptif disajikan dalam tabel 2 berikut ini.

Tabel 2. Hasil Analisis Statistik Deskriptif Kelas Eksperimen dan Kelas Kontrol

\begin{tabular}{|l|l|l|l|l|l|}
\hline & N & Mean & Std. Deviation & Minimum & Maximum \\
\hline Pretest Eksperimen & 25 & 68.20 & 10.396 & 50 & 85 \\
\hline Postest Ekperimen & 25 & 76.00 & 10.897 & 55 & 90 \\
\hline Pretest Kontrol & 26 & 59.81 & 13.227 & 25 & 85 \\
\hline Postest Kontrol & 26 & 71.35 & 13.308 & 40 & 90 \\
\hline
\end{tabular}

Berdasarkan tabel 2 tersebut pada nilai posttest rata-rata yang diperoleh kelas eksperimen lebih besar dari pada kelas kontrol yaitu 76 dan 71,35. Hasil N Gain Score kelas eksperimen memperoleh rata-rata 0,3519 sedangkan pada kelas kontrol 0,2668, 
maka dilihat dari nilai tersebut kedua kelas tersebut berbeda, dimana kelas eksperimen memiliki nilai rata-rata yang lebih besar dari pada kelas kontrol.

Kemudian dilakukan uji normalitas data menggunakan One Sample Kolmogorov - SmirnovZ. Hasil nilai signifikansi kedua kelas lebih besar dari 0,05 maka data berdistribusi normal. Uji homogenitas menggunakan Levene's test, kedua kelas memperoleh hasil nilai signifikansi 0,604 artinya data tersebut homogen.

Setelah uji prasyarat terpenuhi, maka dilanjutkan uji hipotesis. Tujuannya untuk mengetahui ada atau tidak pengaruh setelah diberi perlakuan. Uji hipotesis menggunakan independent sample $t$ test, memperoleh hasil 0,179 dengan taraf kepercayaan $95 \%$, artinya $H_{0}$ diterima. Kesimpulannya tidak terdapat perbedaan pengaruh penggunaan model pembelajaran BBL berbasis eksperimen dengan model pembelajaran konvensional terhadap hasil belajar tema 7 Subtema 3 Peristiwa Mengisi Kemerdekaan pada siswa kelas V SDN Sumberpucung 6.

Selain data hasil pengujian di atas, diketahui juga nilai rata-rata yang diperoleh kelas eksperimen dan kelas kontrol. Nilai rata-rata kelas eksperimen dan kelas kontrol meliputi hasil pretest, posttest, dan $N$ Gain Score. Tabel 3. menunjuukan hasil penghitungan rata-rata nilai pretest, posttest, dan $N$ Gain Score kelas eksperimen dan kelas kontrol adaah sebagai berikut.

Tabel 3. Perbandingan nilai Rata-Rata Pretest, Posttest, dan $N$ Gain Score

\begin{tabular}{|l|l|l|l|}
\hline \multirow{2}{*}{ Kelas } & Nilai Rata-Rata & \multicolumn{3}{|l|}{} \\
\cline { 2 - 4 } & Pretest & Posttest & N Gain Score \\
\hline Ekperimen & 68,20 & 76,00 & 35,19 \\
\hline Kontrol & 59,81 & 71,35 & 26,68 \\
\hline
\end{tabular}

Hasil perbandingan nilai pretest pada kelas eksperimen adalah 68,20 sedangkan kelas kontrol adalah 59,81. Hasil perbandingan nilai posttest pada kelas eksperimen adalah 76,00 sedangkan kelas kontrol adalah 71,35. Hasil perbandingan $N$ Gain Score pada kelas eksperimen adalah 0,3519 sedangkan kelas kontrol adalah 0,2668. Hasil perbandingan data pretest dan posttest pada kelas eksperimen dan kelas kontrol agar lebih jelas disajikan dalam bentuk diagram seperti pada gambar 1. di bawah ini. 


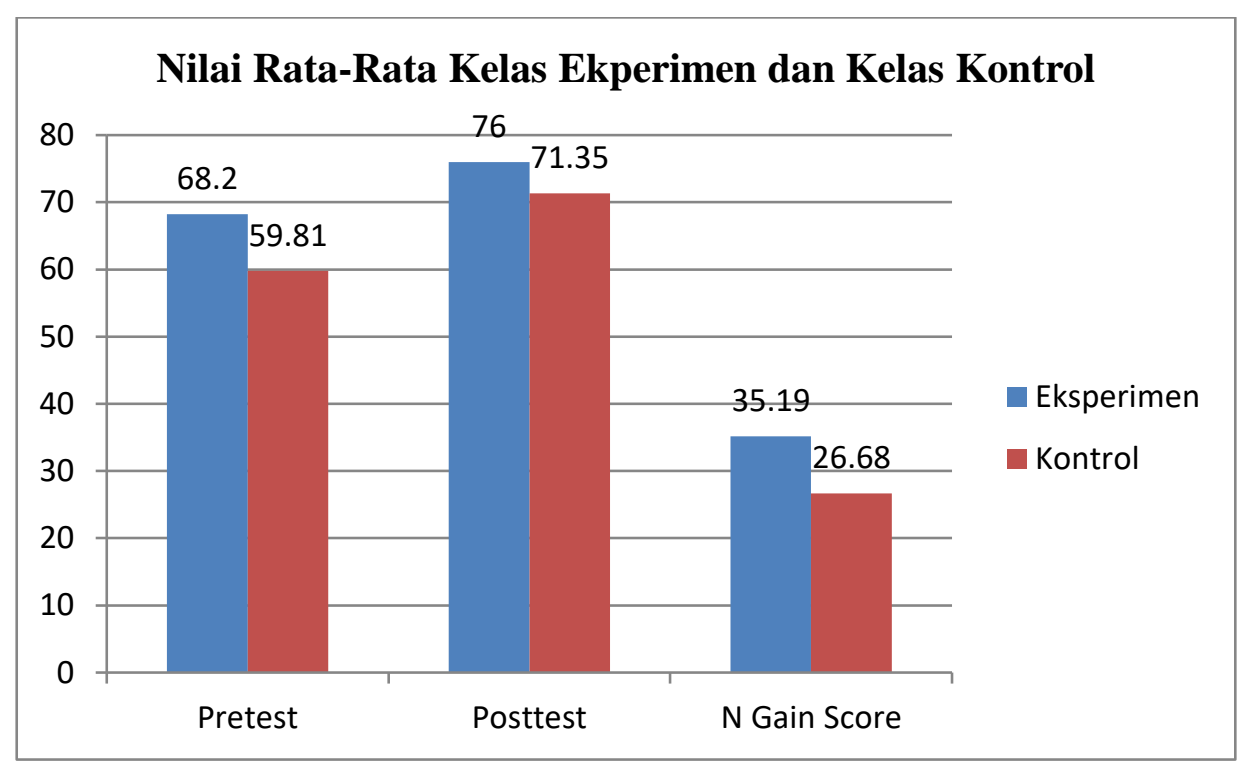

Gambar 1 Nilai Rata-Rata Pretest, Posttest, dan N Gain Score Kelas Ekperimen dan Kelas Kontrol

Tabel 3. dan gambar 1 menunjukkan hasil pretest kelas eksperimen memiliki nilai rata-rata lebih tinggi dibandingkan nilai rata-rata kelas kontrol dengan selisih 8,39. Sedangkan nilai rata-rata posttest kelas eksperimen lebih tinggi dibandingkan dengan nilai rata-rata kelas kontrol dengan selisih 4,65. Nilai rata-rata $N$ Gain Score kelas eksperimen lebih tinggi dari pada kelas kontrol dengan selisish 8,51.

\section{PEMBAHASAN}

Kelas ekperimen menggunakan model pembelajaran BBL berbasis eksperimen. Selama kegiatan pembelajaran kelas ekperimen diamati oleh satu orang observer yaitu guru kelas. Hasil observasi dianalisis memperoleh rata-rata skor keterlaksanaan pada kelas eksperimen adalah 88,3\%. Skor tersebut termasuk dalam kategori baik. Sesuai dengan penelitian dari Istikomah (2019), yaitu dilaksanakannya model pembelajaran BBL dalam kegiatan pembelajaran dapat meningkatkan aktifitas siswa. Siswa tidak tidak jenuh selama proses pembelajaran karena penerapan model pembelajaran BBL dilakukan secara berkelompok serta membuat siswa lebih berperan aktif. Siswa satu dengan siswa lainnya saling bekerja sama dan tiap anggota mengerjakan Lembar Kegiatan Siswa (LKS) sehingga siswa mengalami sendiri materi yang disampaikan pada saat itu. Maka pembelajaran terlaksana dengan lancar dan baik sehingga hasil belajar menjadi meningkat (Istikomah, 2019). 
Kegiatan pembelajaran yang menggunakan model BBL berbasis eksperimen dilakukan dengan pengalaman langsung, kegiatan tersebut bertujuan untuk menyeimbangkan otak kanan dan otak kiri (Jensen, dalam Widyaiswara, 2015:7). Selama kegiatan pembelajaran siswa dapat dengan mudah mengolah informasi yang diterima oleh otak. Sehingga siswa menjadi lebih mudah paham dan mengingat tentang materi yang telah dialami. Di samping itu, siswa juga merasa pembelajaran lebih bermakna dan tidak membosankan. Maka dari itu, siswa di kelas eksperimen mendapat rata-rata yang lebih tinggi. Seperti pada penelitian yang telah dilakukan oleh Esa (2017) yaitu model pembelajaran BBL merupakan model pembelajaran yang bermakna, menyenangkan, dan tidak membosankan. Dikarenakan siswa belajar dengan lingkungan yang mendukung kegiatan pembelajaran serta kegiatan belajar yang berulang-ulang sehingga siswa menjadi lebih paham terhadap materi. Hasilnya adalah kelas ekperimen lebih memahami konsep fisika daripada kelas kontrol.

Hasil yang diperoleh kedua kelas dapat berbeda karena kegiatan pembelajaran kelas eksperimen menggunakan tujuh tahapan (Jensen, dalam Widyaiswara, 2015:7). Pertama, tahap pra pemaparan pada pembelajaran diawali oleh guru memberikan pemahaman awal tentang materi pembelajaran yang akan diperoleh agar tidak terjadi miskonsepsi. Kedua, tahap persiapan, guru menciptakan keingintahuan. Siswa diberi apersepsi untuk memberikan stimulus siswa. Pertanyaan apersepsi tersebut dihubungkan dengan materi yaitu tema 7 subtema 3 peristiwa mengisi kemerdekaan, serta disesuaikan dengan pengetahuan awal siswa. Ketiga, tahap inisiasi dan akuisisi, memberikan bimbingan dan arahan dalam pembelajaran. Keempat, tahap elaborasi, memberikan kesempatan otak untuk memahami, menganalisis, memberikan argumentasi. Siswa berdiskusi dan mencari informasi tambahan dari buku-buku yang dimiliki. Kelima, tahap inkubasi dan memasuki memori, siswa diberi waktu untuk berbagi informasi yang diperoleh dari kegiatan diskusi, eksperimen, dan presentasi. Keenam, tahap verifikasi dan pengecekan keyakinan, guru menjelaskan materi dan menilai pengetahuan siswa dengan memberikan soal evaluasi. Ketujuh, tahap perayaan dan integrasi, diberikan kepada siswa aktif bertanya, berpendapat, dan menjawab pertanyaan-pertanyaan yang diberikan guru selama pembelajaran akan mendapat penghargaan atau reward bintang.

Uraian tahapan di atas menunjukkan bahwa model BBL berbasis eksperimen merupakan model pembelajaran yang bermakna dan menyenangkan. Karena siswa 
melakukan kegiatan dengan pengalaman langsung atau eksperimen. Kegiatan tersebut sesuai dengan penelitian yang dilakukan oleh Mustiada, dkk. (2014) menunjukkan bahwa rata-rata hasil belajar yang diperoleh siswa yang menggunakan model BBL bermuatan karakter lebih besar daripada siswa yang menggunakan model konvensional disebabkan karena adanya perbedaan perlakuan pada sintak pembelajaran. Apabila dalam sintak pembelajaran berbeda maka dalam penyampaian materi saat kegiatan pembelajaran juga berbeda. Sehingga kelebihan dari model pembelajarn BBL dapat terlihat.

Selama proses pembelajaran model BBL berbasis eksperimen kelebihan dan kekurangan tersebut dapat terlihat (Djamarah \& Zain, 2010:84-85). Seperti siswa membuat lingkungan belajar yang aktif untuk mewujudkan kemampuan manganalisis permasalahan, mencari solusi serta alasan dari suatu permasalahan yang timbul ketika proses pembelajaran, dan menantang kemampuan berpikir siswa. Kegiatan pembelajaran dapat berjalan lancar karena tersedianya fasilitas yang memadai untuk pembelajaran ini. Sehingga lingkungan belajar yang menyenangkan dapat tercipta dan menimbulkan motivasi bagi siswa dalam menyampaikan ide atau pendapatnya mengenai materi pelajaran. Kekurangan dari model BBL berbasis eksperimen yaitu tidak semua jenis materi dapat digunakan dengan model ini.

Setelah kegiatan pembelajaran yang dilakukan sesuai dengan prinsip berbasis otak dan eksperimen, memori pengetahuan tentang fakta dan keterampilan dapat tersimpan secara alami pada siswa (Jensen, dalam Widyaiswara, 2015:7). Adanya perubahan dari aspek pengetahuan, sikap, dan keterampilan pada diri siswa tersebut membuktikan bahwa suatu pembelajaran telah mencapai tujuan pembelajaran dengan baik (Susanto, 2013:5). Didukung dengan hasil evaluasi yang baik, sebagai tindak lanjut dalam mengukur kemampuan siswa.

Faktor eksternal dan faktor internal menjadi penyebab perolehan hasil belajar yang berbeda-beda (Susanto, 2013:12). Faktor eksternal seperti kondisi lingkungan belajar dikelas dari mulai sampai selesainya kegiatan pembelajaran. Faktor internal, siswa memiliki semangat tinggi melakukan kegiatan pembelajaran, didukung dengan keadaan jasmani dan rohani siswa yang baik. Maka mewujudkan lingkungan belajar yang kidmat. 
kesimpulannya kelas ekperimen dengan model pembelajaran BBL berbasis eksperimen tidak ada pengaruh terhadap hasil belajar tema 7 subtema 3 peristiwa mengisi kemerdekaan siswa V. Namun pada rata-rata hasil posttest kelas eksperimen lebih tinggi yaitu 76, dan memenuhi Kriteria Kelulusan Minimal (KKM) yang ditetapkan oleh sekolah yaitu 75 .

\section{SIMPULAN}

Kesimpulan yang diperoleh dari hasil dan pembahasan ialah hasil pretest dan posttest kelas eksperimen menunjukkan data berdistribusi normal, homogen, dan uji hipotesis adalah 0,015 dan 0,179. Artinya model pembelajaran tersebut tidak ada pengaruh terhadap hasil belajar siswa kelas $\mathrm{V}$ peristiwa mengisi kemerdekaan. Sedangkan hasil pretest dan posttest kelas kontrol yaitu data berdistribusi normal, homogen, dan uji hipotesis adalah 0,015 dan 0,178. Artinya model pembelajaran konvensional tidak ada pengaruh terhadap hasil belajar tema 7 subtema 3 peristiwa mengisi kemerdekaan siswa kelas V. Namun nilai rata-rata posttest kelas eksperimen lebih tinggi dibandingkan dengan kelas kontrol dengan selisih 4,65. Nilai rata-rata $N$ Gain Score kelas eksperimen juga lebih tinggi dari pada kelas kontrol dengan selisish 8,51 .

\section{UCAPAN TERIMAKASIH}

Saya ucapkan terimakasih yang sebesar-besarnya, kepada keluargaku, dosen pembimbing, dan teman-teman. Penelitian ini dapat berjalan lancar berkat motivasi, dan dukungan dari orang-orang disekitar saya.

\section{DAFTAR RUJUKAN}

Awarlin, Rima. 2019. Efektivitas Model Jigsaw dengan Two Stay Two Stray pada Materi FBP dan KPK di Kelas IV SDN Bendo 1. Skripsi tidak diterbitkan. Malang: UM

Dimyati dan Mudjiyono. 2013. Belajar dan Pembelajaran. Jakarta: Rineka Cipta

Djamarah, Syaiful Bahri, Dkk. 2010. Strategi Belajar Mengajar. Jakarta: Rineka Cipta

Efendi, Mohammad. 2009. Kurikulum dan Pembelajaran: Pengantar Ke Arah Pemahaman KBK, KTSP dan SBI. Malang: FIP UM 
Esa, Riza Billy Sasmita. 2017. Pengaruh Model Brain Based Learning Terhadap Pemahaman Konsep Fisika Siswa Kelas XI MIA MAN 1 Malang. Skripsi tidak diterbitkan. Malang: UM

Ibrahim. 2017. Perpaduan Model Pembelajaran Aktif Konvensional (Ceramah) dengan Kooperatif (Make-A Match) untuk Meningkatkan Hasil Belajar Pendidikan Kewarganegaraan. Jurnal Ilmu Pendidikan Sosial, Sains, Humaniora. UIN Sultan Syarif Kasim Riau Vol.3. Dari https://ejournal.uinsuska.ac.id/index.php/suaraguru/article/view/3597/

Indriani, Fitri. 2016. Kompetensi Pedagogik Mahasiswa dalam Mengelola Pembelajaran Tematik Integratif Kurikulum 2013 pada Pengajaran Micri di PGSD UAD Yogyakarta. Jurnal. Universitas Muhammadiyah Surakarta Vol: 2. Dari https://journals.ums.ac.id/index.php/ppd/article/view/1643.

Istikomah. 2019. Penerapan Model Pembelajaran Brain Based Learning (BBL) untuk Meningkatkan Hasil Belajar pada Tema Ekosiste Peserta Didik Kelas V MIN Bandar Lampung. Skripsi tidak diterbitkan. Lampung: UIN Raden Intan Lampung.

Laksmi, Sujana, Suryaabadi. 2014. Pengaruh Model Pembelajaran Berbasis Otak (Brain Based Learning) Berbantuan Teka-Teki SilangTerhadap Hasil Belajar IPS Siswa Kelas V SD Gugus 1 Gusti Ngurah Jelantik. Jurnal. Universitas Pendidikan Ganesha Vol: $2 . \quad$ Dari https://ejournal.undiksha.ac.id/index.php/JJPGSD/article/view/2055.

Mustiada, Agung, dan Antari. 2014. Pengaruh Model Pembelajaran BBL (Brain Based Learning) Bermuatan Karakter Terhadap Hasil Belajar IPA. Jurnal. Universitas Pendidikan Ganesha Vol: $2 . \quad$ Dari https://ejournal.undiksha.ac.id/index.php/JJPGSD/article/view/2250.

Nahdi, Dede Salim. 2015. Meningkatkan Kemampuan Berpikir Kritis dan Penalaran Matematis Siswa Melalui Model Brain Based Learning. Jurnal. Cakrawala Pendas, $\quad 1(1), 13^{-} \quad 22 . \quad$ Dari https://www.neliti.com/id/publications/266386/meningkatkan-kemampuanberpikir-kritis-dan-penalaran-matematis-siswa-melalui-mod.

Prasojo, Sarwo Edi \& Zain, Aswan. 2012. Peningkatan Kualitas Pembelajaran IPA Melalui Metode Eksperimen Berbasis Lingkungan Siswa Kelas I SDN Ngaliyan 01 Semarang. Tesis tidak diterbitkan. Semarang: Pascasarjana Universitas Negeri Semarang.

Sugiyono. 2019. Metode Penelitian Pendidikan Kuantitatif, Kualitatif,Kombinasi, R\&D dan Penelitian Pendidikan. Bandung: Alfabeta

Susanto, Ahmad. 2013. Teori Belajar \& Pembelajaran di Sekolah Dasar. Jakarta: Kencana

Widyaiswara, Rudi. 2015. Pembelajaran Berbasis Kemampuan Otak pada Pembelajaran Matematika untuk Orang Dewasa. Artikel. E-Buletin Edisi April, 1-11. Dari https://adoc.tips/pembelajaran-berbasis-kemampuan-otak-pada-pembelajaran$\underline{\text { matem.html }}$ 